\title{
Chemical Characterization and Fatty Acid Composition of Different Sesame Verities
}

\author{
Varsha Thakur ${ }^{1}$, Seema Paroha ${ }^{2 *}$ and Ravi Prakash Mishra ${ }^{1}$
}

${ }^{1}$ Environmental Biotechnology Laboratory, Department of P. G. Studies and Research Biological

Science, Rani Durgavati University, Pachpedi, Jabalpur 482001, Madhya Pradesh, India

${ }^{2}$ Biochemistry Laboratory of Project Coordination Unit, All India Coordination Project (Sesame and Niger), Jawaharlal Nehru Krishi Vishwavidyalaya, Jabalpur 482004, Madhya Pradesh, India

*Corresponding author

\section{A B S T R A C T}

Ke y w o r d s
$\begin{aligned} & \text { Sesame (sesamum } \\ & \text { indicum L.), Free } \\ & \text { Fatty Acid } \\ & \text { composition and } \\ & \text { Chemical } \\ & \text { characterization. }\end{aligned}$
Article Info
Accepted:
15 October 2017
Available Online:
10 December 2017

10 December 2017
The fatty acid composition is a great significance for determination of the oil quality. The quality is especially based on the palmitic, stearic, oleic and linoleic acid. Sesame is the most ancient crop traditionally it is grown during kharif season in most part of the country. Its seeds contain between 50 and $54 \%$ of very good semi-drying oil, mostly with palmitic and stearic acids. In this research, variation in oil content, oil yield, chemical composition and fatty acid composition of 7 different TKG-22, GT-10, PKVNT-11, PRACHI, HT-2, DSS-9 and TMV-7 sesame verities were investigated. The oil content varied 39.33 to 46.4 . percentage content of, linoleic acid, palmitic, Stearic acids, oleic acid and linolinic acid in the seed oil ranged between 31.84 to $41.73 \%, 8.33$ to $10.15 \%, 5.34$ to 7.0 and respectively. Oleic acids 39.88 to $48.81 \%$, linoleic acids 0.25 to $0.50 \%$ and palmitoleic 0.10 to $0.13 \%$ acids were the minor fatty acids of sesame as sesame were about $24.3 \%$ which increases the suitability of the sesame oil for human consumption. The oil could be useful as edible oils and for industrial applications. In conclusion, the fatty acid composition of determinate types was found to be satisfactory.

\section{Introduction}

For human nutrition fats and oils is one of the most intricate and arguable areas of analysis in nourishment science (Hayakawa et al., 2000). Dietary fat is perceived to be the "worst" of all the nutrients in stimulating divers of ailment, akin cardiovascular disease (CVD), diabetes, obesity, and others. Nevertheless, among macronutrients, dietary fat is the most energy intensive; it does play an important role in assuring that we meet our daily energy requirements and enables the amalgamation of fat-soluble vitamins. The amount of TFA in the diet is of interest because of the possible adverse effects of these isomers with respect to cardiovascular disease, infant development, diabetes and inflammation (Schmidt, 2006). Oilseeds are second only to grain crops in the supply of plant proteins for human and animal consumption. Sesame seed (Sesamum indicum), an oilseed plant of the Pedaliaceae family, is cultivated on a worldwide basis for both oil and protein (Sen and Bhattacharyya, 2001). Sesame is an excellent source of oil (57-63\%) (Uzun et al., 2003), protein (2325\%) (Anilakumar et al., 2010), carbohydrate 
(20-25\%) and ash (5 \%) (Borchani et al., 2010). Sesame Seeds contain significant amounts of oxalic acid (2.5\%) (Kapadia et al., 2002). Additionally, sesame seeds fats comprise about 2.25 times as much energy as the equal amount of carbohydrates from foodgrains or forages (Choi et al., 2008).

Sesame seed is rich in polyunsaturated fatty acids viz. omega-6-fatty acids and unsaturated fatty acids where the fatty acids composition is $14 \%$ saturated $39 \%$ mono-unsaturated and $46 \%$ poly-unsaturated fatty acids (Toma and Tabekhia, 1979). Sesame oil is a superior vegetable oil and has a pleasant flavor. It ranks second after olive oil with regard to nutritional value. Worldwide, fatty acids composition in sesame oil is variable among the different cultivars of sesame seeds such as black, brown and white.

Oil composition of sesame seeds depends on different factors such as climatic situation, soil condition and ripeness of plant (Rahman et al., 2007). Fatty acids that are present in abundance are oleic (44\%), linoleic (34\%), palmitic $(10 \%)$ and Stearic $(7 \%)$ acids which mutually comprise about $95 \%$ of the total fatty acids (Yoshida et al., 2000).

Sesame oil is used after exposure to wind or sun to calm the burns. It nourishes and feeds the scalp to control dry scalp, and kill dandruff causing bacteria. It has been successfully used in the children's hair to kill lice infestations. Sesame oil is mildly laxative, emollient and demulcent. The oil has wide medical and pharmaceutical application.

\section{Materials and Methods}

The experimental study has been conducted at the Biochemistry laboratory, Project Coordinating Unit (Sesame and Niger), JNKVV. Jabalpur. The material used and method employed during the course of investigation on identification of suitable genotypes for expression for chemical traits in sesame are presented in this chapter

\section{Procurement of raw material}

In this study seven sesame varieties are taken Two national checks TKG-22 (national check), GT-10 (National check), and five verities PKVNT-11, PRACHI, HT-2, DSS-9 and TMV-7) of four different seed colors (viz. white, black, light brown and dark brown) procured from Project Coordinating Unit (Sesame and Niger) JNKVV, Jabalpur.

\section{Methods}

Proximate analysis of Sesamum indicum L. seed crude protein (micro-Kjeldahl), crude oil contents were determined using the NMR equipment (Oxford Analytical Make), whereas the total carbohydrate was determined by anthrone method. Free Fatty Acid composition by Gas Chromatography method. Oxalic acid was determined using the method of titration by (AOAC). All determinations were done in triplicate.

\section{Estimation of oil in seed sample}

Oil content of each sesame varieties was estimated by using NMR equipment (Oxford Analytical Make) in the laboratory, Project Coordinating Unit (Sesame and Niger), J.N.K.V.V. Jabalpur. A composite seed sample of each treatment was taken to analyze the oil content $(\%)$.

\section{Estimation of free fatty acid in seed sample}

Composition of fatty acid was determined using method ISO 5508 (1990). Before analysis, fatty acids (FAs) were converted to fatty acid methyl esters (FAMEs) by shaking a solution of $60 \mathrm{mg}$ oil and $3 \mathrm{~mL}$ of hexane with $0.3 \mathrm{~mL}$ of $2 \mathrm{~N}$ methanolic potassium 
hydroxide. FAs were analyzed by gas chromatography using a Varian CP-3800 (Varian Inc.) chromatograph equipped with a FID. The column used was a CP-Wax 52CB column $(30 \mathrm{~m} \cdot 0.25 \mathrm{~mm}$ i.d.; Varian Inc., Middelburg, The Netherlands). The carrier gas was helium and the total gas flow rate was $1 \mathrm{~mL} / \mathrm{min}$.

The initial and final column temperature was $170^{\circ} \mathrm{C}$ and $230^{\circ} \mathrm{C}$, respectively, and the temperature was increased by steps of $4^{0} \mathrm{C} / \mathrm{min}$. The injector and detector temperature was $230^{\circ} \mathrm{C}$. Data were processed using a Varian Star Workstation v 6.30 (Varian Inc., Walnut Creek, CA, USA). Results were expressed as the relative percentage of each individual FA present in the sample.

\section{Estimation of protein by micro kjeldahl method}

Multiplying the nitrogen content value 6.25 with protein content of sesame seed, which also includes non-protein nitrogen. To get true protein content, deduce the non-protein nitrogen from crude protein content and then multiplying with the factor. The crude protein content (\%) sesame seed was worked out by following formula (A.O.A.C. 1965).

Crude protein $\%=\mathrm{N}$ content $(\%) \times 6.25$ (as a constant factor).

\section{Carbohydrate content by an-throne method}

Carbohydrate content of the sesame seed sample was determined according to anthrone method as described by (AOAC, 1990).

Absorbance of unknown / Concentration of unknown $=$ Absorbance of standard $/$ Concentration of standard.

\section{Oxalic acid percentage by titration method}

Oxalic acid content of the sesame seed sample was determined according to titration method as described by (AOCS, 1980)

Oxalic acid \% =

$6.303 \mathrm{X}$ normality of $\mathrm{KMnO}_{4} \mathrm{X}$ Volume of $\mathrm{KMnO}_{4}$

Weight of seed sample (gm.)

\section{Statistical analysis}

Values represented are the means and standard deviations for three replicates. Statistical analysis was carried out by Excel Version 8.0.

The economic importance of sesame is determined by the quantity of oil contains. The highest oil content was recorded in variety GT-10 (46.4 \pm 0.4$)$ Lowest value of oil content was recorded in varieties PKVNT-11 (39.33 \pm 1.15$) \quad$ (Table 1 and Fig. 1) respectively. The oil content of some cultivars in Anotaly a located in the Mediterranean Region of Turkey was reported to be range of 43.42 to $49.47 \%$ by (Yilmaz et al., 2005).

\section{Protein (\%)}

The highest protein content was recorded in variety TKG-22 (16.7 \pm 0.17$)$. Lowest value of protein content was recorded in varieties DSS-9 (11.7 \pm 0.52$)$ (Table 1 and Fig. 2). This is less than mean values of 24.63 and 21.78 reported by Borchani et al., (2010).

\section{Carbohydrate (\%)}

The highest carbohydrate content was recorded in variety GT-10 (18.5 \pm 0.4$)$.Lowest value of carbohydrate content was recorded in varieties DSS-9 $(11.47 \pm 0.75)$ (Table 1 and Fig. 3) is also low when is compared with the reported by (Ogbonna et al., 2013). 


\section{Oxalic acid (\%)}

The highest oxalic acid content was recorded in variety GT-10 (1.63 \pm 0.2$)$. Lowest value of oxalic acid content was recorded in varieties PKVNT-11 (0.15 \pm 0.03$)$ (Table 1 and Fig. 4). This is close to 1.64 reported by (Borchani et al., 2010).

Fatty acid distribution of sesame oils is presented in Table 2. The major saturated fatty acids in Sesamum indicum L seed oil were palmitic, Stearic acids and main unsaturated fatty acids are linoleic and oleic acids Linoleic acid which is one of the most important polyunsaturated fatty acids in human food because of its prevention of distinct heart vascular diseases (Boelhouwer, 1983).

\section{Palmitic acid}

Palmitic acid is the major saturated fatty acid of sesame seed oil (Crews et al., 2006) in this study highest palmitic acid (\%) was recorded in variety GT-10 (10.15\%).Lowest value of palmitic acid (\%) was recorded in varieties PRACHI (8.33\%) (Table 2) Turgut and Baydar (1996) reported the sesame cultivars of the South East Region of Turkey were palmitic acid $(9.7 \%)$, the findings of this study are close to the results of Sowmya et al., (2009) and palmitic (8.67\%), illustrated by Nzikou et al., (2009).

Table.1 Biochemical composition of different sesame verities

\begin{tabular}{|c|c|c|c|c|c|}
\hline S.NO. & Verities name & Oil percentage & Protein & Carbohydrate & Oxalic Acid \\
\hline 1 & TKG-22 & $40.33 \pm 1.15$ & $16.7 \pm 0.17$ & $17.6 \pm 0.49$ & $0.92 \pm 0.02$ \\
\hline 2 & GT-10 & $46.4 \pm 0.4$ & $16.43 \pm 0.45$ & $18.5 \pm 0.4$ & $1.63 \pm 0.2$ \\
\hline 3 & PKVNT-11 & $39.33 \pm 1.15$ & $12.13 \pm 0.35$ & $12.76 \pm 0.23$ & $0.15 \pm 0.03$ \\
\hline 4 & PRACHI & $44.47 \pm 0.45$ & $16.4 \pm 1.45$ & $11.97 \pm 0.3$ & $0.87 \pm 0.03$ \\
\hline 5 & HT-2 & $40.5 \pm 0.45$ & $12 \pm 0.45$ & $17.3 \pm 0.52$ & $0.33 \pm 0.05$ \\
\hline 6 & DSS-9 & $40.33 \pm 0.57$ & $11.7 \pm 0.52$ & $11.47 \pm 0.75$ & $0.68 \pm 0.2$ \\
\hline 7 & TMV-7 & $44.7 \pm 0.43$ & $15 . .37 \pm 0.41$ & $16.43 \pm 0.5$ & $0.94 \pm 0.03$ \\
\hline
\end{tabular}

Table.2 Fatty acid compositions of different sesame verities

\begin{tabular}{|c|c|c|c|c|c|c|c|c|}
\hline S.No & Fatty Acid & $\begin{array}{l}\text { S-1 Area } \\
(\%)\end{array}$ & $\begin{array}{l}\text { S-2Area } \\
(\%)\end{array}$ & $\begin{array}{l}\text { S-3 Area } \\
(\%)\end{array}$ & $\begin{array}{l}\text { S-4Area } \\
(\%)\end{array}$ & $\begin{array}{l}\text { S-5Area } \\
(\%)\end{array}$ & $\begin{array}{l}\text { S-6Area } \\
(\%)\end{array}$ & $\begin{array}{l}\text { S-7Area } \\
(\%)\end{array}$ \\
\hline 1 & $\begin{array}{c}\text { Palmitic } \\
\text { Acid }\end{array}$ & 9.39 & 10.15 & 9.94 & $\mathbf{8 . 3 3}$ & 9.77 & 9.70 & 9.36 \\
\hline 2 & $\begin{array}{c}\text { Palmitolic } \\
\text { Acid }\end{array}$ & 0.10 & 0.11 & 0.13 & 0.10 & 0.13 & 0.12 & 0.13 \\
\hline 3 & $\begin{array}{c}\text { Stearic } \\
\text { Acid }\end{array}$ & 5.51 & 5.61 & 6.14 & 5.68 & 6.86 & 5.34 & 7.00 \\
\hline 4 & Oleic Acid & 41.36 & 39.88 & 43.86 & 41.71 & 42.48 & 41.60 & 48.81 \\
\hline 5 & $\begin{array}{c}\text { Linoleic } \\
\text { Acid }\end{array}$ & 41.25 & 41.73 & 37.24 & 41.67 & 38.26 & 41.52 & 31.84 \\
\hline 6 & $\begin{array}{c}\text { Linolinic } \\
\text { Acid }\end{array}$ & 0.35 & 0.32 & 0.26 & 0.50 & 0.26 & 0.28 & 0.25 \\
\hline
\end{tabular}

Where S1- TKG-22, S2- GT-10, S3- PKVNT-11, S4- PRACHI, S5- HT-2, S6-DSS-9 and S7-TMV-7 

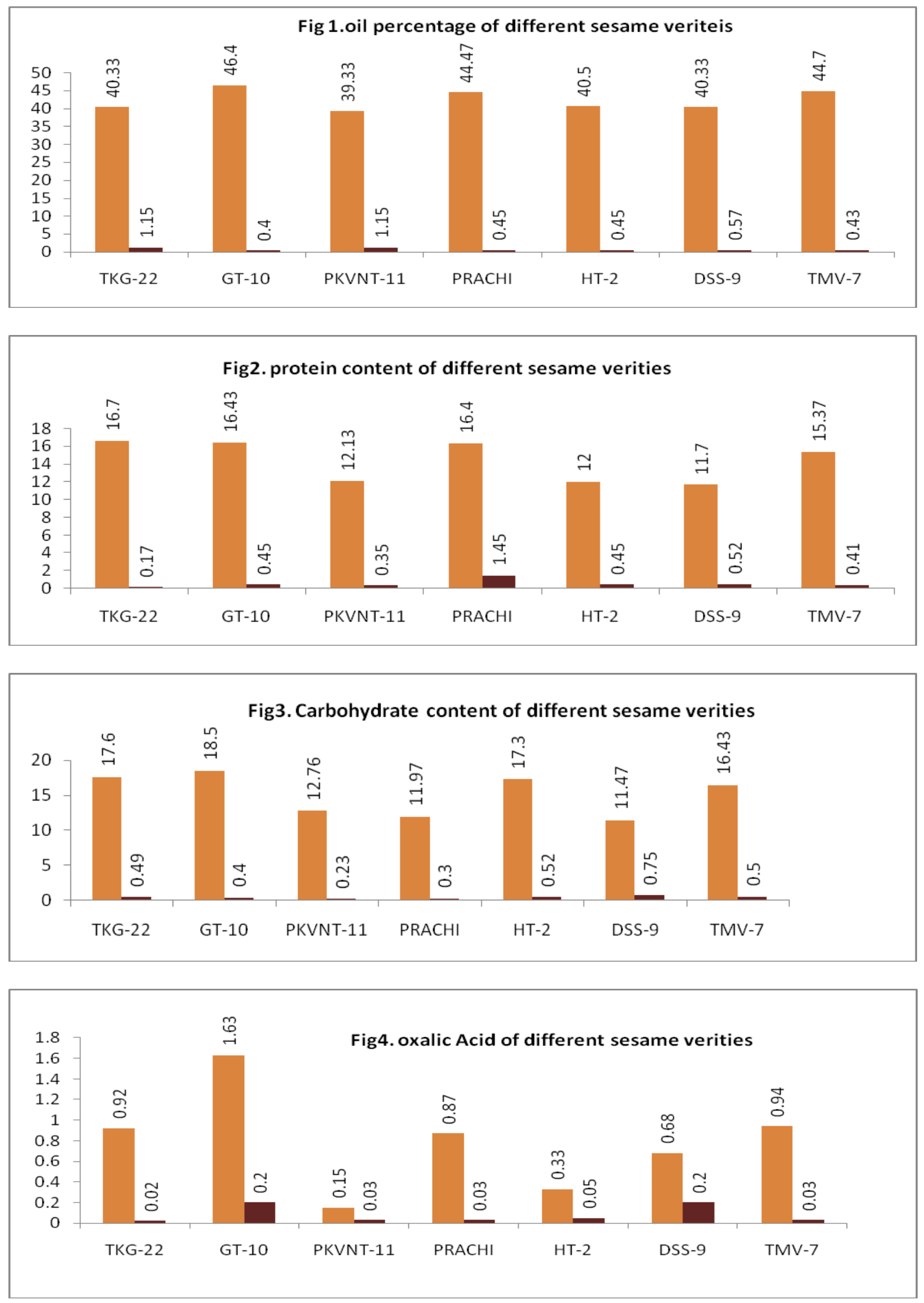


\section{Palmitolic acid}

Different sesame verities are not showed a major difference in palmitolic acid of sesame oil according to this study highest palmitolic acid was recorded in variety TMV-7, PKVNT-11 and HT-2 (0.13 \%).Lowest value of palmitolic acid was recorded in varieties TKG-22 and PRACHI (0.10\%) (Table 2).

\section{Stearic acid}

It is the main saturated fatty acid in sesame oil. In this study highest Stearic acid percentage was recorded in variety TMV-7 (7.0\%). Lowest value of Stearic acid (\%) was recorded in varieties DSS-9 (5.34\%) (Table 2). These results are agreement with Stearic (5.56\%) acids as illustrated by Nzikou et al., (2009) and (Murwan et al., 2007).

\section{Oleic acid}

It is the main monounsaturated fatty acid of sesame seed oil (Crews et al., 2006) in this study highest oleic acid percentage was recorded in variety TMV-7 (48.81\%).

Lowest value of oleic acid percentage was recorded in varieties GT-10 (39.88\%) (Table 2). Turgut and Baydar (1996) reported the sesame cultivars of the South East Region of Turkey were oleic acid (45.3\%).

The findings of this study are close to the results of Sowmya et al., (2009) and (Murwan et al., 2007).

\section{Linoleic acid}

The highest linoleic acid percentage was recorded in variety GT-10 (41.73\%). Lowest value of linoleic acid content was recorded in varieties TMV-7 (31.84\%) (Table 2) these findings are close to the results of Sowmya et al., (2009) and Murwan et al., (2007).

\section{Linolinic acid}

The highest linolinic acid percentage was recorded in variety PRACHI $(0.50 \%)$. Lowest value of linolinic acid content was recorded in varieties TMV-7(0.25\%) (Table 2) this study is close to the results of Sowmya et al., (2009). Results of all free fatty acids are agreement with the findings of other authors (Hassan, 2012; Sabah El Khier et al., 2008; Ogbonna and Ukaan; 2013; Nzikou et al., 2009; Unal and Yalcin, 2008).

The aim of this study is to determine the fattyacid compositions of sesame samples obtained from different varieties and to compare it. Seven sesame samples were collected from JNKVV Jabalpur in order to determine the oil yield, chemical composition and fatty-acid compositions. The oil squeez exhibited good chemical properties and could be useful for industrial application.

\section{Acknowledgement}

Authors are owe heartfelt thanks to Head, Dept. of P.G. Studies and Research in Biological Science, R.D. University, and Project Coordination Unit, All India Coordination Project (Sesame and Niger), Jawaharlal Nehru Krishi Vishwavidyalaya, Jabalpur for bestowing Lab facilities

\section{References}

Alasalvar, C., Taylor, K. D. A., Zubcov, E. Shahidi, F., and Alexis, M. 2002. Differentiation of cultured and wild sea bass (Dicentrarchus labrax): total lipid content, fatty acid and trace mineral composition. Food Chemistry, 79: 145.

Anilakumar, K.R., Pal. A., Khanum F. and Bawa, A.S. 2010. Nutritional, medicinal and industrial uses of sesame (Sesamum indicum L.) seeds: An overview. Agric. Conspec. Science. 75:159-168. 
Association of Official Analytical Chemicals (AOAC). 1990. Official methods of analysis. Inc. 16th edn. Arlington, USA.

Borchani, C., Besbes, S., Blecker, C.H. and Attia, H. 2010. Chemical Characteristics and Oxidative stability of Sesame Seed, Sesame Paste, and Olive Oils. Journal of Agriculture Science and Technology, 12: 585-596.

Choi, A. M., Lee, S. B., Cho, S. H., Hwang, I., Hur, C. G., and Suh, M. C. 2008. Isolation and characterization of multiple abundant lipid transfer protein isoforms in developing sesame seeds. Journal of Plant Physiology and Biochemistry, 46(2): 127.

Crews, C., Hough, P., Godward, J., Brereton, P., Lees, M., Guiet, S., Winkelmann, W. 2006. Quantitation of the main constituents of some authentic grapeseed oils of different origin. Journal of Agriculture Food Chemistry, 54: 62616265 .

Hassan, Manal A. M. 2012. Studies on Egyptian sesame seeds (Sesamum indicum L.) and its products 1 physicochemical analysis and phenolic acids of roasted Egyptian sesame seeds (Sesamum indicum L.). Journal of World Dairy and Food Science. 7 (2), 195-201.

ISO 5508. 1990. Animal and vegetable fats and oils - analysis by gas chromatography of methyl esters of fatty acid

Kapadia, G. J., Azuine, M. A., Tokuda, H., Takasaki, M., Mukainaka, T., Konoshima, T., Nishino, H. 2002. Chemopreventive effect of resveratrol, sesamol, sesame oil and sunflower oil in the Epsteinbarr virus early antigen activation assay and the mouse skin two-stage carcinogenesis. Pharmacology Res. 45: 499-505.

Nzikou, M., Matos, L. Bouanga, G. K., Kalou, C. B., Ndangui, N. P., Pambou,
G., Kimbonguila, A., Silou, T. Linder, M. and Desobry, S. 2009. Chemical composition on the seeds and oil of sesame (Sesamum indicum L.) grown in Congo-Brazzaville. Advance Journal of Food Science and Technology, 1: 6-11.

Ogbonna, C. E., Enete, I. C, Alozie, G. C. and Ejekwu, G. I. 2013. Air pollution tolerance index if selected plants in the vicinity of an automobile repair and service area in Okigwe, South East Nigeria. World Environment, 3(5): 161164.

Pigott, G. M., and Tucker, B. W. 1987. Science opens new horizon for marine lipids, in human nutrition. Food Review International, 3: 105-138.

Rahman, M. S., Hossain, M. A., Ahmed, G. M., and Uddin, M. M. 2007. Studies on the characterization, lipids and glyceride compositions of Sesame (Sesamum indicum linn.) Seed Oil. Bangladesh. Journal of Sci. Ind. Res. 42:67-74.

Sabah El Khier, M. K., Khogali Elnur, A. I., Abu El Gasim, A. Y. 2008. Chemical composition and oil characteristics of sesame seed cultivars grown in Sudan. Res. J. Agric. Biol. Sci. 4 (6), 761-766.

Schmidt, M. C. C. 2006. World-wide consumptions of trans fatty acids, Atherosclerosis Supplements, 7: 1-4.

Sen, M., and Bhattacharyya, D. K. 2001. Nutritional Quality of Sesame Seed Protein Fraction Extracted with Isopropanol. Journal of Agriculture and Food Chemistry, 49: 2641-2646.

Sowmya, M., Jeyarani, T., Jyotsna, R., Indrani, D. 2009. Effect of replacement of fat with sesame oil and additives on rheological, microstructural, quality characteristics and fatty acid profile of cakes. Food Hydrocolloids, 23: 18271836.

Teco Finance Export, 2005. Information produced- Unrefined olive oil of 
Sesame. http://www.huile.com/INFO sesame.pdf

Toma, R. B., and Tabekhia, M. M. 1979. Phytate and oxalate contents in sesame seed. Nutr Rep Int., 20: 25-31.

Unal, M. K., and Yalcin, H., 2008. Proximate composition of Turkish sesame seeds and characterization of their oils. Grasas Y Aceites 59 (1), 23-26.

Yılmaz, A., Boydak, E., Beyyavaş, V., Cevheri, İ., Haliloğlu, H., and Güneş, A. 2005. Şanlıurfa ekolojisinde ikinci ürün olarak bazı susam (Sesamum indicum L.) çeşit ve hatlarının yetiştirilme olanakları üzerinde bir araştırma. Türkiye VI. Tarla Bitkileri Kongresi, Antalya. Journal of Turkish Thoracic, pp. $425-429$

Yoshida, A., Shigezaki, H., Takagi S., and Kajimoto, G. 2000. Variation in the composition of various acyl lipid, Tocopherols and lignans in sesame seed oil roasted in a microwave oven. J. Sci. Food Agri. 68: 407-415.

\section{How to cite this article:}

Varsha Thakur, Seema Paroha and Ravi Prakash Mishra. 2017. Chemical Characterization and Fatty Acid Composition of Different Sesame Verities. Int.J.Curr.Microbiol.App.Sci. 6(12): 1936-1943. doi: https://doi.org/10.20546/ijcmas.2017.612.221 